http://www.sciforum.net/conference/wsf-4

World Sustainability Forum 2014 - Conference Proceedings Paper

\title{
Zero Emission Buildings in Korea
}

\author{
Thorsten Schuetze $^{1, *}$, Petra Hagen Hodgson ${ }^{2}$ \\ ${ }^{1}$ Department of Architecture, Sungkyunkwan University, 2066 Seobu-ro Jangan-gu, \\ Suwon-si, Gyeonggi-do 440-746, Korea \\ ${ }^{2}$ ZHAW Zurich University of Applied Sciences, Department Life Sciences und Facility Management, \\ Gruental, Postfach, 8820 Waedenswil, Switzerland \\ E-Mails: t.schuetze@skku.edu; petra.hodgson@zhaw.ch \\ * Author to whom correspondence should be addressed; E-Mail: t.schuetze@skku.edu; \\ Tel.: +82-1-4947-6774; Fax: +82-31-290-7570. \\ Received: / Accepted: / Published:
}

\begin{abstract}
This paper discusses the history, the status quo, and future prospects of Zero Emission Buildings (ZEBs) in the Republic of Korea, illustrated by good practice examples. The advantages of, and requirements for, ZEBs are described, concerning the sectors energy, water, nutrients and biomass. ZEBs are characterized by net zero energy consumption through minimization of the service energy demand, which is covered with locally produced renewable energy. The direct water footprint is reduced up to $100 \%$ through on-site water supply and wastewater management according to the principles of Integrated Water Resource Management and Sustainable Sanitation. The fresh water demand is reduced through application of water efficient systems, as well as the collection, processing, recycling and reuse of wastewater for non-drinking purposes. Rainwater harvesting, storage, utilization and infiltration for augmentation of groundwater facilitates onsite freshwater supply and drinking water production from rainwater and groundwater. Nutrients and biomass from kitchens and sanitation systems are processed on-site and are recycled for local horticulture and agriculture. Traditional Korean buildings can be generally defined as ZEBs. With modernization and implementation of state of the art centralized infrastructure systems in the $20^{\text {th }}$ century also traditional know-how and practice regarding the sustainable operation of buildings and resource management has been forgotten. However, since the beginning of the $21^{\text {st }}$ Korean citizens, policymakers, scientists and companies have a growing interest in sustainability issues. This much promising trend is
\end{abstract}


also reflected by a growing number of research and development activities, including the construction and operation of ZEBs.

Keywords: Korea; Zero Emission Buildings; energy efficiency; energy productivity; sustainable sanitation; urban agriculture.

\section{Introduction}

The sustainable uses of resources plays a key-role in the global challenge to cope with extensive resource consumption, exceeding the natural capacity of our planet, and the related environmental, economical and social impacts. The building sector plays a significant role in this regard because the portion of the global recourses consumption is 33\%. The portion of the total global energy consumption is $40 \%$, and most of the anthropogenic $\mathrm{CO}_{2}$ emissions result from the burning of fossil fuels [1]. Conventional food production is also responsible for a large portion of the global $\mathrm{CO}_{2}$ emissions (primary caused by land use change, from soil carbon losses and chemical fertilizer production) and energy consumption for farming, harvesting, storage, and transport of agricultural products. Furthermore conventional farming is globally responsible for most of the anthropogenic freshwater consumption [2].

The production of food and drinking water and the management of wastewater are generally decoupled, resulting in environmental pollution and the elimination of resources. In contrast, sustainable infrastructure systems should involve effective, efficient and integrated local resources management, based on the principles of sustainability and circular flow economies. Centralized infrastructure systems for water management generally include high monetary costs, the lockup of capital for very long periods, they are associated with limitations in provision and discharge, and are difficult to adapt to changing demographic structures [3]. In contrast, the decentralization and building integration of infrastructures for the management of energy, water, and organic waste implies many advantages $[4,5,6,7]$. Appropriate decentralized system approaches for efficient supply, use, treatment, recycling, and reuse of resources facilitate the realization of so called zero-emission buildings [3].

This paper discusses the development so-called Zero Emission Buildings (ZEBs) in the Republic of Korea. After a brief general definition of ZEBs by using specific criteria, traditional and present Korean buildings will be described. Furthermore it will be analyzed to which degree specific buildings meet the criteria of ZEBs. The emissions of traditional and present buildings are compared with each other by using qualitative and quantitative criteria. The analysis of current general building practices, best practice examples for ZEBs, and policy trends regarding the implementation of ZEBs facilitates the formulation of expected future development trends of ZEBs in the Republic of Korea.

The described research is based on the authors own investigations executed in the framework of an international and interdisciplinary research project on ZEBs by means of personal discussions, field studies and analysis of recent published and unpublished research results and documentation of best practice examples of ZEBs in Korea. The research project with the title "Zero Emission Buildings, Integrating Sustainable Technologies and Infrastructure Systems (ZEBISTIS)" involves partners from Germany, Republic of Korea, Switzerland, and Turkey, and runs over a period of two years from 2012 
until the end of 2014 [8]. The research project is executed in the framework of and supported by the Korean scientific cooperation network with the European Research Area - 2012 Joint Call on Green Technologies [9].

The operation of ZEBs should not produce any harmful emissions, neither to the atmosphere, to water nor to the ground, but on the contrary have even positive environmental impacts due to the production of resources such as renewable energy, fresh water, biomass and fertile soil. The ZEBISTIS project fosters the exchange of newest developments and compilation of best practice examples in order to accelerate the development of decentralized and building integrated services engineering technologies and infrastructure systems for sustainable operation of buildings by innovative system configuration of single technologies as well as their application and marketing in Europe and Korea. In the following sections of this research paper, the history, the status quo and the future perspectives of ZEBs in Korea are discussed.

\section{Results and Discussion}

\subsection{Zero emission aspects of traditional Korean buildings}

The traditional Korean building type, the so-called "Hanok", has been adapted over centuries to provide inhabitants a comfortable indoor climate and to suite the specific temperate climate zone in Korea, which is characterized by four seasons, cold and dry winter, hot and humid summer, as well as mild spring and autumn [10].

The residential buildings for one family generally consisted of detached single-story buildings surrounded by a garden and arranged around an unpaved courtyard. Residential buildings in cities represented a compact variation of residential farmhouses. The floor plan layout was generally rectangular or L-shaped. The spatial separation between the private property, the road and neighboring properties consisted generally of walls made from natural stones and/ or earth and burned bricks. The single buildings were accessed via the courtyard, which was connected with the road via a gate in the surrounding wall. Spatially, the courtyard could be regarded as an extension of the interior space of the surrounding buildings [11].

Traditional buildings are built with the regionally available and partly renewable materials timber, clay, sand, straw and stone. The whole building construction is elevated on an architrave block (Figures 1\&2, [12]) to protect the building from splash water and ascending moisture. The borders of the architrave block are designed parallel to the eaves and are protected from rainwater by roof overhangs. The buildings have two different floor constructions, which are assigned to two different room types. Comparable big and open rooms with well-ventilated timber floors are called Malu. These rooms are also characterized by open ceilings and big windows, which can be widely opened, and are designed to facilitate cross ventilation, passive cooling, and provide a comfortable indoor climate, particularly during the warm seasons. Comparable small rooms with suspended ceilings, small windows, and equipped with floor heating systems (Ondol) are called "Bang" and are designed to provide a comfortable indoor climate particularly during the cold seasons (Figure 1, [12]). The room configuration and the design are clearly determined. Variations of the building design are based on the modification of the basic structure [12]. 


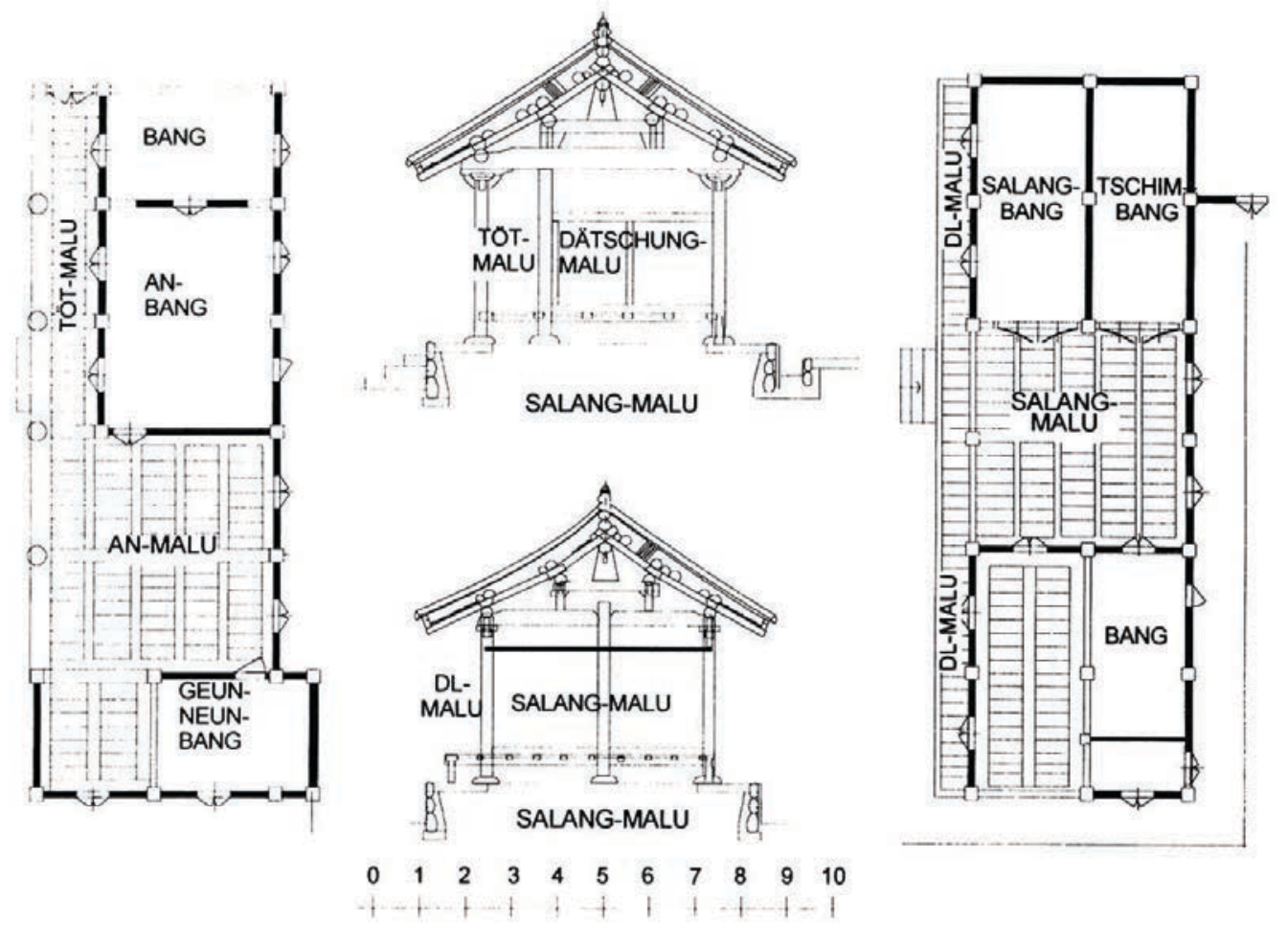

Figure 1. Floor plans and sections of traditional Korean residential with specification of rooms designed for comfortable indoor climate during cold seasons (Bang, equipped with the floor heating system Ondol) and living areas designed for comfortable indoor climate during the warm seasons (Malu, without heating systems and equipped with well ventilated timber floors and high ceilings).

\section{Solar altitude at noon}

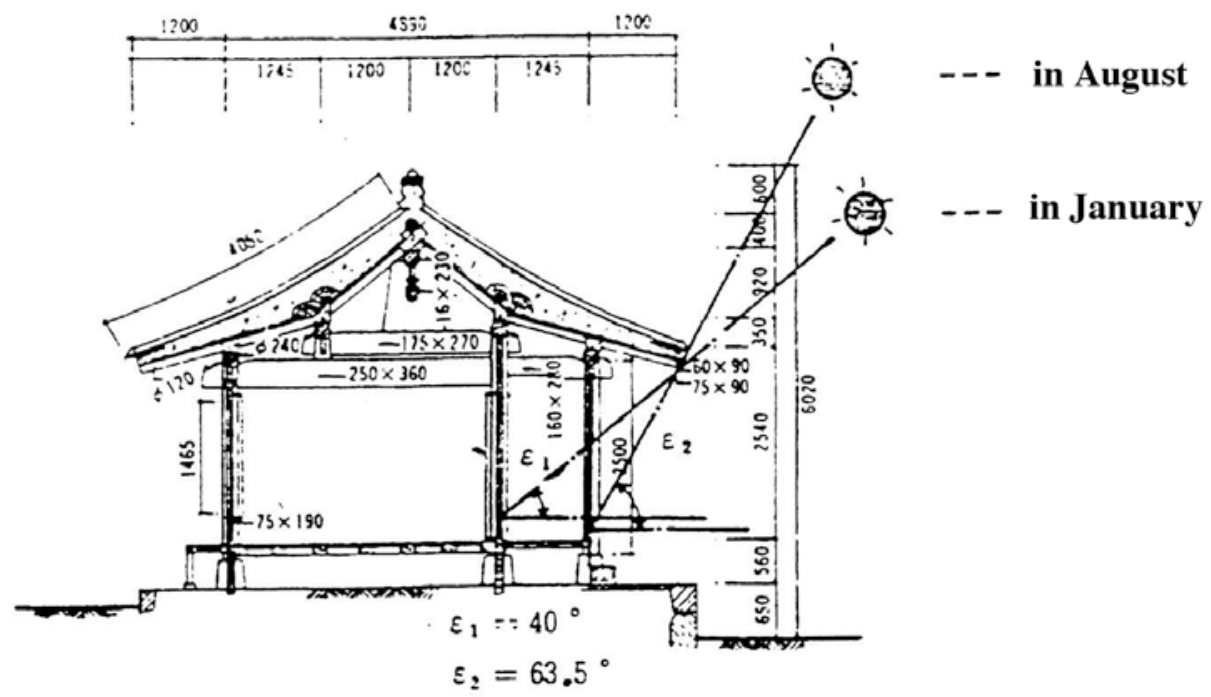

Figure 2. Section drawing of a traditional Korean building, with illustration of solar altitudes at noon during summer (August) and winter (January). 
The building structure consists of a timber framework. The wall surfaces between the vertical timber columns and horizontal beams are either closed with translucent or opaque fillings. Translucent fillings are generally open able windows consisting of a timber grid structure, which is covered with mulberry paper. Opaque fillings are closed with a meshwork consisting of timber branches or bamboo, plastered with clay. The roof consists of a heavy multilayered timber roof construction. The roofing consists either of straw or burned brick tiles laid on a clay layer [12].

The design of traditional buildings is very well adapted to the Korean climate to provide a comfortable indoor climate with minimized additional technical effort, which is generally in contrast to contemporary architectural design (Figure 3, [13]). During the hot and humid summer passive cooling is provided by cross ventilation, shading by wide projecting roof, and protection from radiant heat by roof construction with big thermal mass. During the sunny but cold winter the indoor climate can be controlled during the day by opening of the windows and making use of passive heating by direct solar radiation. However due to relatively thin walls and windows indoors are cool down easily. For the provision of a comfortable warm indoor climate, Bang rooms are equipped with the floor heating system Ondol. The system consists of a fireplace, which is originated at one side of the building, and is used as a stove for the preparation of food and hot water. The exhaust gases are led horizontally through a meandering ductwork, situated under the floor of the Bang rooms. A chimney is situated on the opposite building side of the fireplace to release the exhaust gases, which are used to heat the floor of the Bang room. Both ductwork and floor are constructed with stones and clay. The floor finish consists of fine clay layer laminated with mulberry paper varnished with a bean oil coating. The heating systems and stove is fired with renewables such as timber, straw or charcoal. The double function and synergy between cooking and heating is only used during the heating period to enhance fuel efficiency and to avoid overheating of indoors during the non- heating periods [12].

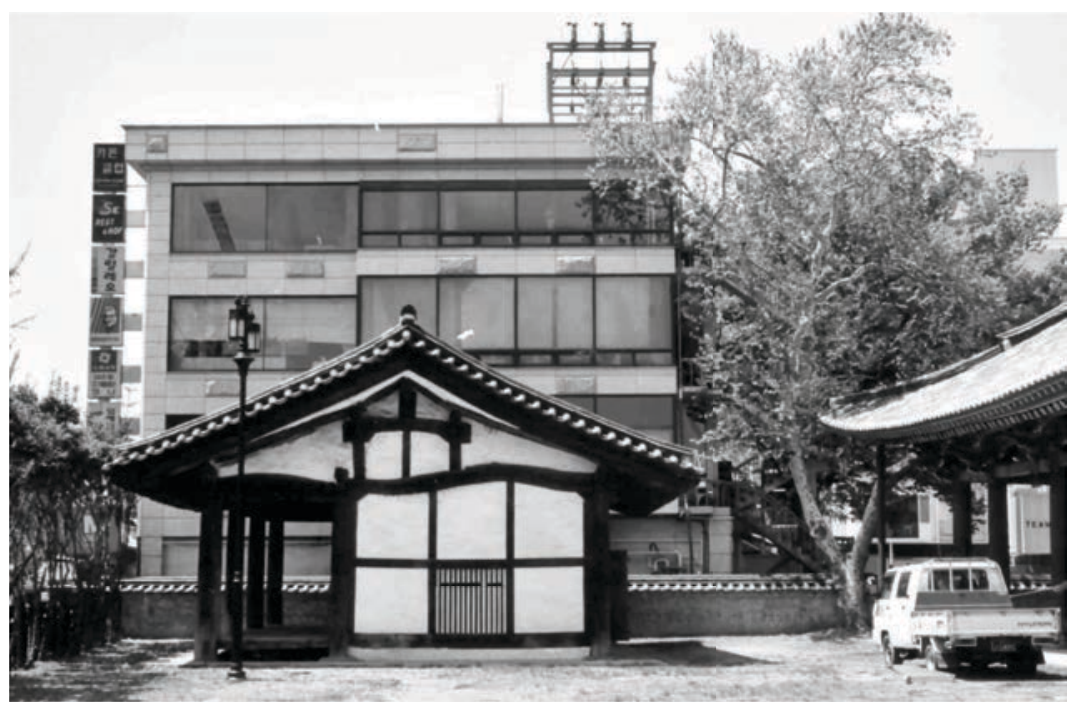

Figure 3. Traditional climate responsive Korean building in front of contemporary Korean building in international style with significant heating and cooling demand.

Originally, traditional Korean buildings were neither equipped with electrical installations nor with fresh water supply and sewerage systems. Drinking water is traditionally withdrawn from natural springs, streams or collectively used groundwater wells, depending on the specific natural basic 
conditions of a settlement, and has been transported manually to private properties. Therefore and due to the seasonally significantly varying precipitation and changing water availability (the majority of precipitation falls during the summer months), water is used traditionally in a conscious and efficient way. Stormwater, for example, was not directly drained away but was partly collected and utilized onsite. Work, which required comparable high amounts of water, e.g. the washing of laundry, was generally done next to surface water bodies, such as streams or rivers (Figure 4, [14]).

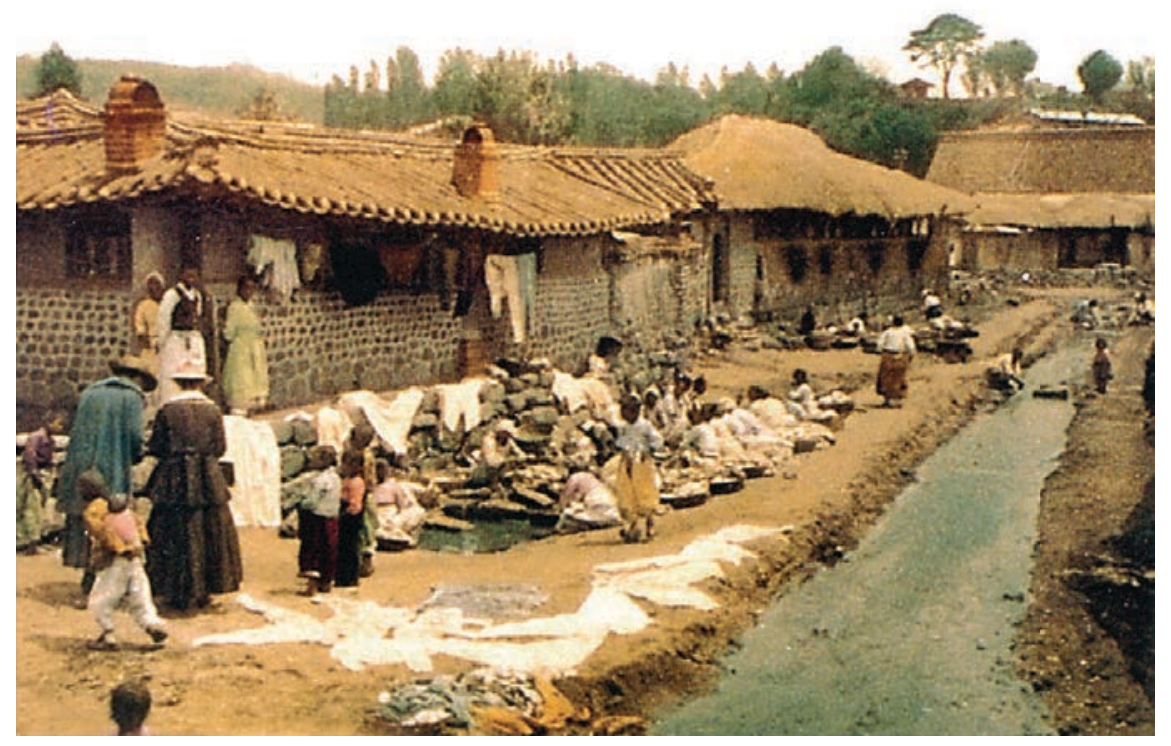

Figure 4. Washing laundry at a city stream in Seoul in the year 1890.

Even used greywater is traditionally reused, for example for irrigation of plants. The very small proportion of sealed surface areas influenced the natural water cycle to a very small degree. Surplus water is infiltrated and only discharged if the soil of a property or the associated public space (street) is completely saturated. Greened gardens and courtyard areas in traditional villages and cities serve as small recreational and ecological buffer areas with a positive influence on the local microclimate, facilitating the farming of small amounts of vegetable and fruits [12]. The layout of traditional settlements regarding placement of build up areas and roads is closely related to the specific topography and the location of natural streams, which were used for the drainage of surplus rainwater, from both natural and built up areas. The roads were generally arranged parallel to streams while buildings were located on higher elevated grounds to be protected from pluvial flooding.

Traditional sanitation, organic waste and farming systems in Korea were closely connected and met zero emission criteria. Urine, faeces and organic residues, e.g. from food production were not regarded as wastes but used as precious resources. "It was well known that urine and faeces could enhance land fertility. The high value of composted excreta for food production is reflected in the old Korean proverb: "You can always give away a bowl of rice, but never a bag of compost". It was also known that faeces had to be handled in a safe way as they could cause illness. As a consequence, the application of fresh, uncomposted faeces was only allowed in early spring or in autumn after the harvest. Until the beginning of the twentieth century, a graded pricing system existed for the marketing of different types of faeces collected from households and transported to agricultural areas outside the 
cities [5]. Various kinds of toilets were used in cities as well as in rural areas to collect excreta for reuse, with the type of toilet depending on the conditions of each location:

- Pot-toilets were mainly used in urban areas. Due to the limited space the excreta, mixed with ash, was collected regularly and carried out of the city to designated sites where it was composted (Figure 5, [15]).

- Temple toilets were used in temples. They are dehydration toilets, whose working principle is based on the collection and drying of faeces on-site (Figure 5, [15]).

- Pig-toilets were used mainly in rural areas. Human faeces were consumed directly after defecation by animals (particularly pigs).

- Ash-toilets were used in areas with relatively low building density and near agricultural land. The faeces were stored and composted on-site [16]." [2]
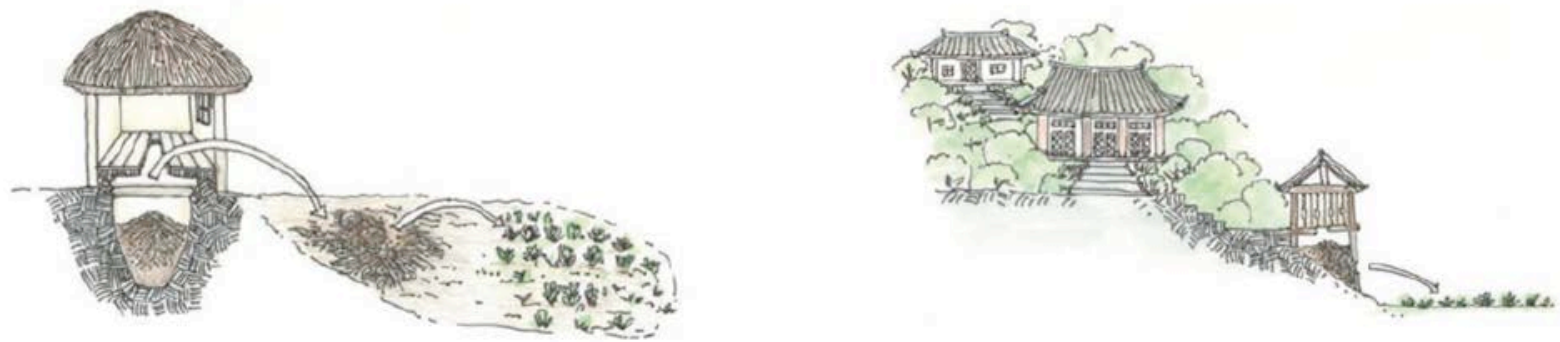

Figure 5. Left: Traditional pot-toilet in Korea. Right: Temple-toilet next to houses and agricultural areas.

The ZEBs approach discussed in the framework of this paper focus on the operation of buildings and does generally not primary discuss emission aspects related to the construction, maintenance and deconstruction of buildings. However, Korean traditional buildings are not only operated but also built and maintained in a sustainable way. The zero emission related design, building construction and maintenance related concepts of traditional Korean buildings can be assigned to the following aspects.

- The use of environmentally friendly materials with high resource productivity minimizes the total mass and energy flow related to the production of building materials.

- The utilization of local and traditional materials minimizes transportation efforts and allows the preservation of the cultural identity and knowledge in the built environment.

- Renewable materials maximize the carbon dioxide storage.

- Durable components and materials facilitate long-term use and reduce maintenance, renovation and refurbishment needs during a building's lifetime.

- Building components and materials can be reused, refurbished and recycled.

- Multifunctional design extends the utilization-orientated life cycle of a building and facilitates easy conversion, modification or extension for different building uses.

- Maintenance-friendly design, which is well adapted to the local climate and building use, extends the lifetime of building and construction materials.

- Deconstruction and reuse friendly design enables the extensive, non-destructive deconstruction of the building structure and selected exchange of specific building components. 
Accordingly, the traditional construction and operation of traditional Korean buildings and settlements can be regarded as conform to the concept of ZEBs, and as sustainable according to ecological, economical and social criteria. However, due to the single-story architecture, the settlement density in Korea is traditionally very low. The growing population and urbanization in the $19^{\text {th }}$ century resulted therefore in an area intensive expansion of settlement areas [17,18].

\subsection{Modern Korean buildings and infrastructure systems - renunciation from zero emission concepts}

During the Japanese occupation of Korea, in the period from 1909 until 1945, modern industrialized materials, buildings and centralized infrastructures systems following the western paradigm, were introduced to Korea. However, the Korean population built their houses still with traditional materials and in the traditional way. Also after liberation and the area wide destructions of the Korean War, most residential building in Korea were built according to traditional typologies but to a growing extend with industrialized materials, such as cement blocks for walls and either fiber cement or burnt brick tiles for roofing. The built up area in Seoul for example consisted until 1970 to over $88 \%$ of singlestory building with open courtyards. Attended with the economic growth and development of Korea, particularly in cities like Seoul, traditional building structures were replaced by multi-story buildings connected to centralized infrastructures, for water supply, sewage management, electricity and gas supply, and paved road infrastructures. By 1990 the percentage of single story building types of the total building stock had been declined to approx. 46\% (Figure 6, [19]) [18].

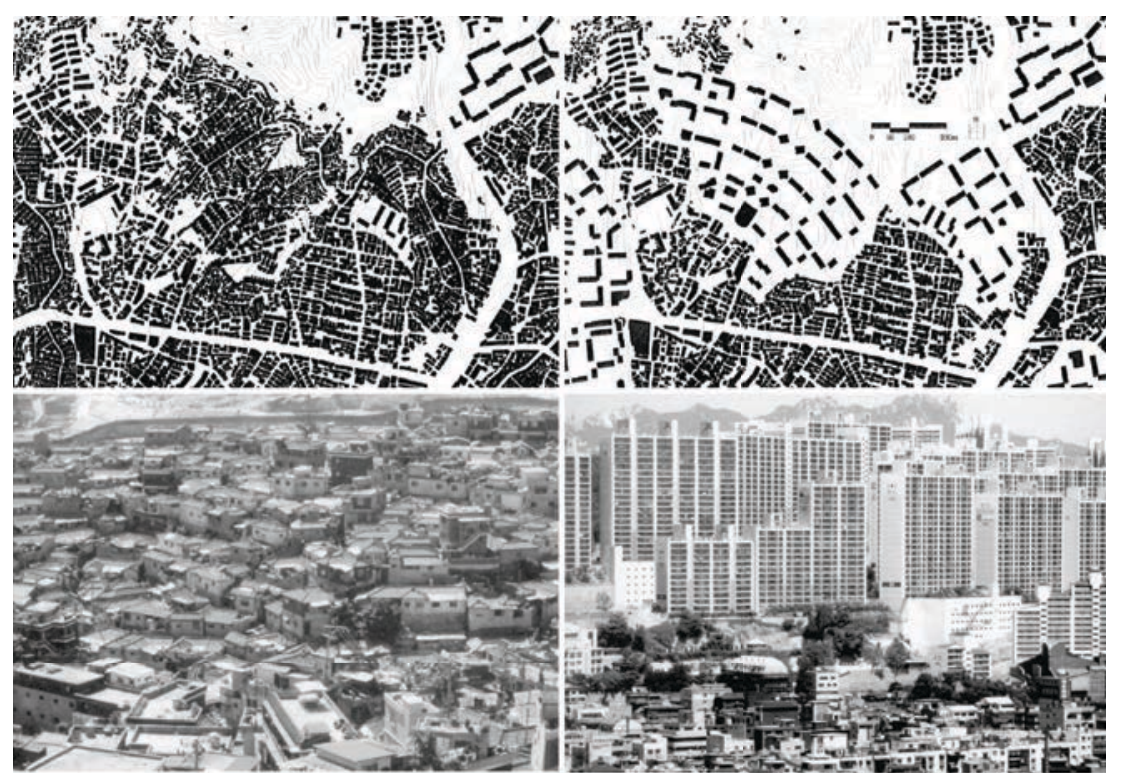

Figure 6. Example of an area wide urban remodeling area before demolishment of existing buildings (left top and bottom), and after finalization of new apartment district construction (right top and bottom).

Induced by new urban planning guidelines the traditional mix of functions in urban neighborhoods was eliminated in urban redevelopment and new development projects. Therefore the need for mobility and commuting compared with traditional urban developments increased significantly due to spatial separation of residential, industrial and commercial areas. New high-rise apartment buildings were 
constructed according to modern principles in form of cast in situ concrete constructions. In contrast to traditional buildings, apartments have clearly structured functional areas, such as kitchen, bathroom, sleeping rooms, living and dining rooms, as well as sore and laundry rooms. Contemporary apartments are equipped with centralized floor heating systems powered generally either with gas or electric boilers, to provide comfortable indoor climate during the cold seasons. For the provision of a comfortable indoor climate during the warm seasons, apartments are equipped with air conditioning systems. Until the end of the 1990 apartment buildings were realized with approximately 15 stories. Since the end of the 1990 buildings were realized with 30 stories, and since the last 10 years apartment buildings are generally built with 45, and even more stories. Floor plans of older buildings with comparable small number of elevations and lower building heights allow for natural cross ventilation, which could be regarded as a passive cooling measure. Furthermore the facades of older apartments are equipped with glazed balconies which serve as thermal buffer zones and static shading elements of secondary facades, which separate the balcony space from the indoors. Modern high-rise apartments are often attached to a central core equipped with mechanical ventilation and do not facilitate cross ventilation. New apartments have generally no balconies and only one façade without exterior shading elements. Accordingly, the architecture of contemporary apartments is generally less adapted to the Korean climate than older apartments or traditional Korean architecture [13].

The current indoor comfort temperature of approximately 24 Degrees Celsius in Korea requires warmer indoor temperatures during the winter and colder indoor temperatures during the summer. Accordingly the energy demand for heating and cooling per area unit was generally increasing. However, more compact building design, represented by a lower building envelope to usable area ratio in Koran apartments buildings compared to smaller single or multifamily houses, could contribute to lower transmission heat losses [10].

Drinking water supply, wastewater and rainwater management in contemporary South Korean settlements is centralized. Drinking water is generally produced from surface water, extracted from lakes, which are formed from dammed streams. Due to input from urbanized and agricultural areas the surface water has to be significantly purified by multiple processes before it is meeting drinking water quality and is supplied via drinking water supply networks to the users. The drinking water consumption in South Korea is comparable high. The average domestic drinking water consumption in Seoul is 208 liters per person and day, without considering the pipeline losses of the centralized supply network of $8 \%$, and is responsible for $70 \%$ of the total urban drinking water consumption [20]. The drinking water consumption in Seoul for example exceeds the available renewable water resources significantly. Considering the average rainfall of $1282 \mathrm{~mm} /$ year, the total average amount of rainwater landing on the city area would be $775,610,000 \mathrm{~m}^{3}$, which is similar to only $89.4 \%$ of the standard domestic drinking water demand [21]. In the catchment area of the Han River where more than 26 Million people live [22], almost 50\% of the total yearly average runoff is extracted for freshwater supply of urbanized and agricultural areas. Due to the significant seasonal differences in rainfall, the proportion of extracted freshwater can exceed the natural river discharge [23].

The wastewater in cities is collected via centralized sewer networks and is generally purified in sewage treatment plants. Big apartment complexes are equipped with own treatment facilities. The treated wastewater is generally discharged in surface water bodies, which serve as fresh water reservoirs for domestic, industrial or agricultural water supply [5]. 
The stormwater from built up areas is generally collected together with wastewater in mixed sewerage systems. During intensive precipitation events, which occur mostly during the summer months, mixed sewage overflows result in significant pollution of surface water bodies. The reason for the discharge of untreated mixed sewage is the limited storage and treatment facilities of the mixed sewage drainage and treatment facilities, which already operate with maximum capacity during dry weather flow[5]. Nutrient rich Sewerage sludge is generally disposed off or incinerated [24] and to a limited degree of $30 \%$ applied as fertilizer in organic agriculture [5].

Organic and food waste in Korea is generally collected and processed to compost by thermal composting processes. The organic matter can therefore be reused in horticulture and agriculture and does therefore meet partly (concerning the reuse of organic carbon) the criteria of a zero emission concept. However the transport and processing of organic food waste with high water content is an energy intensive process, which is related with emissions from the burning of fossil fuels.

\subsection{Zero Emission aspects in Korean development roadmaps}

The building energy contributes to $21 \%$ of the total Korean final energy consumption and is expected to increase to $40 \%$. In order to lower the total final energy consumption it is therefore necessary to improve the energy efficiency of buildings in Korea.

According to the Korean energy roadmap, the energy efficiency of new buildings has to be improved ongoing from 2012 to 2025, when new building constructions should have net zero energy consumption and non-residential buildings should have an energy saving rate of $60 \%$ (see Table 1 , $[25,26])$.

\begin{tabular}{|c|c|c|c|c|}
\hline Year & 2009 & 2012 & 2017 & 2025 \\
\hline $\begin{array}{l}\text { Building energy } \\
\text { efficiency category }\end{array}$ & $\begin{array}{c}\text { Energy intensive } \\
\text { house } \\
\end{array}$ & Low energy house & $\begin{array}{l}\text { Passive } \\
\text { house }\end{array}$ & $\begin{array}{c}\text { Zero energy } \\
\text { house } \\
\end{array}$ \\
\hline $\begin{array}{l}\text { Energy saving rate } \\
\text { Residential Buildings }\end{array}$ & $0 \%$ & $30 \%$ & $60 \%$ & $100 \%$ \\
\hline $\begin{array}{l}\text { Energy saving rate non- } \\
\text { residential buildings }\end{array}$ & $0 \%$ & $15 \%$ & $30 \%$ & $60 \%$ \\
\hline $\begin{array}{l}\text { Specific reduction } \\
\text { factors }\end{array}$ & $\begin{array}{c}0 \% \text { reduction of heating } \\
\text { and cooling energy } \\
\text { demand } \\
\end{array}$ & $\begin{array}{c}50 \% \text { reduction of heating } \\
\text { and cooling energy } \\
\text { demand } \\
\end{array}$ & $\begin{array}{c}90 \% \text { reduction of } \\
\text { heating and cooling } \\
\text { energy demand } \\
\end{array}$ & $\begin{array}{l}90 \% \text { reduction of heating and } \\
\text { cooling energy demand }\end{array}$ \\
\hline $\begin{array}{l}\text { Applied improvement } \\
\text { measures (building } \\
\text { envelope \& services } \\
\text { engineering system) }\end{array}$ & $\begin{array}{c}7 \mathrm{~cm} \text { thermal insulation, } \\
\text { double glazing, high } \\
\text { efficiency boiler }\end{array}$ & $\begin{array}{l}15 \mathrm{~cm} \text { thermal } \\
\text { insulation, triple glazing, } \\
\text { mechanical ventilation } \\
\text { with heat recovery }\end{array}$ & $\begin{array}{c}25 \mathrm{~cm} \text { thermal } \\
\text { insulation, high } \\
\text { efficiency windows, } \\
\text { LED lighting }\end{array}$ & $\begin{array}{l}25 \mathrm{~cm} \text { thermal insulation, } \\
\text { high efficiency windows, } \\
\text { LED lighting, renewable } \\
\text { energy production }\end{array}$ \\
\hline
\end{tabular}

Table 1. Development of energy saving rates and exemplary measures of new building constructions in the Republic of Korea according to the national energy roadmap.

The national plan is to optimize the energy efficiency and productivity of Korean buildings with multiple measures defined in the so-called "Building Energy Efficiency Program" (BEEP). Specific 
targets values for the energy efficiency of different building types will be defined in the building code and be part of the construction permit conditions. Furthermore separated design criteria for "construction", "machinery", "electric facilities", and "renewable energy" are described in the building code. A building energy efficiency rating certification system for newly build or renovated apartment and office buildings is also part of the BEEP. The energy efficiency of specific buildings will be assigned to 5 different grades, from 1 - most energy efficient to 5 - less energy efficient, based on the simulation of primary energy performance. The system has been introduced voluntarily already in 2001. 541 Apartment complexes and 201 office buildings have been graded in the 10 years period until 2011. Due to the voluntary character of the rating systems only a comparable small number of buildings has been evaluated. Another part of the BEEP is a management system for Green House Gases (GHG) and Energy Targets (ET). The participation in the program is compulsory for owners of buildings that emit more than 25,000 tons $\mathrm{CO}_{2}$ per year [26].

The Korean building energy policy envisions the realization of a low carbon, green society by expanding the green building sector. The goal is to reduce the GHG emissions of the building sector by $27-31 \%$ by 2020 . The strategy to achieve this goal can be assigned to the following key-points:

1. Strengthening of building energy regulations and standards

2. Improvement of energy efficiency of existing buildings

3. Encouragement of building users energy conscious behavior

4. Development of green building technologies and infrastructure systems.

Strengthening of both building energy regulations and standards aims for the reduction of the heating and cooling energy demand of buildings. The maximum u-values for windows and doors have been for example already minimized from $3.84 \mathrm{~W} / \mathrm{m}^{2} \mathrm{~K}$ in 2001 to $3.0 \mathrm{~W} / \mathrm{m}^{2} \mathrm{~K}$ in 2008 , to $2.4 \mathrm{~W} / \mathrm{m}^{2} \mathrm{~K}$ in 2010 and $1.5 \mathrm{~W} / \mathrm{m}^{2} \mathrm{~K}$ since 2012. Furthermore the installation of items for the reduction of the cooling energy load, standby power programs, LED lighting, and highly energy efficient appliances have to become compulsory. Building permit systems should be in future based on the evaluation of a building's energy demand, and should require the net zero energy performance for all new buildings in the Republic of Korea. However, to achieve the goal for significant reduction of the overall energy consumption of the building sector, not only new buildings but also particularly the energy efficiency optimization of the existing building stock has to be addressed.

The average expected lifetime of apartment buildings in Korea is only 20 years, which is a very short period compared with Japan (30 years), Germany (79 years), France (85 years), USA (103 years) and England (140 years). In 2002 more than $44 \%$ of the residential building stock older than 22 years were apartments [27]. By 2014 approximately $60 \%$ of the South Korean population lives in apartment buildings [28]. Apartment buildings are realized with increasing density, also in direct neighborhood of districts with low-rise multi and single-family houses. Drivers for developments with increasing building heights and densities are primary economical aspects, such as the aim to increase value enhancement by reduction of land consumption in relation to useful built up area [18,29].

The number of aged apartments is rapidly increasing and it is expected that in future, the demolishment and reconstruction of apartments becomes more difficult due to decreased business potentials, caused by slump in the estate business. This trend is reflected by the fact that the portion of apartments with an age of more than 20 years in relation to the total apartment stock increased from 
$15.2 \%$ in 2005, to $32.4 \%$ (see Figure 7, [28]). The total number of apartment unites older than 21 years in 2012 was 1.691 Million. Massive construction of apartments was realized in the 1980s. A growing portion of buildings constructed in that period is becoming more than 30 years old [28].

Accordingly, the development of systematic maintenance policies for aged apartments, in order to extend the buildings lifetime, to improve the energy efficiency [28] together with reduction of hazardous emissions and improvement of living quality are inevitable for sustainable development.

The improvement of energy efficiency of existing buildings is addressed by the Korean building energy policy through promotion of public sector's voluntary labeling of annual energy use, $\mathrm{CO}_{2}$ emissions and facility performance of buildings when there are rented or sold. Incentives for the participation in energy efficiency and green building certifications are for example tax reduction or relaxation from building standards (such as increase of floor to area ratio limitations). 1 Million existing homes, with a focus on social housing, will be "greened" from 2010 to 2018. 1/3 of old buildings should be remodeled, addressing improvement of energy efficiency, supported by policy funded favorable loans.

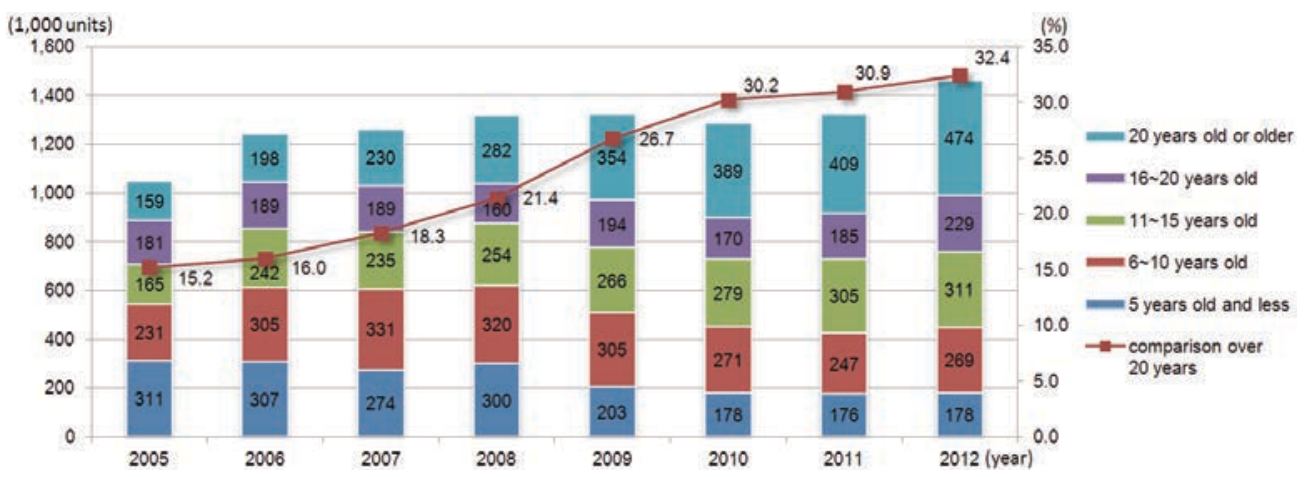

Figure 7. Development of the apartment building stock in the Republic of Korea, from 2005 - 2012 (in apartment units and percentage of total).

Compared with the building energy sector, which has a clear roadmap for the reduction of emissions related to the provision of energy, visions, plans or roadmaps for the reduction of building emissions related to the sectors water, nutrients and organic waste have officially not been defined in the Republic of Korea. Measure for the optimization of infrastructure systems for water supply and wastewater treatment focus generally on leakage control, as well as enhancement of drainage, retention and treatment capacities of centralized infrastructure system. Decentralized measures for diffuse stormwater pollution control by so-Called LID (Low Impact Developments) and flood control by decentralized retention and management of rain- and stormwater are discussed to a growing extend and many products and systems are available on the Korean market. However, an area wide application is not yet supported by policies, e.g. by compulsory regulations or provision of incentives. However, the important role of integrating more green areas for recreational and ecological purpose is addressed in several initiatives. The lack of green spaces in Korean cities, for instance in Seoul where more than 80 $\%$ of green areas are concentrated in suburban areas in the form of mountain forests, is addressed here by the Seoul Metropolitan Government who works on the creation of easily accessible green parks in urban areas [30]. 
Existing regulation focus primarily on the reduction of drinking water consumption, e.g. by rainwater management harvesting and utilization and/ or the recycling of wastewater. To reduce the urban drinking water consumption, the national water act of South Korea requires hotels, shopping malls and industries, exceeding a specific water consumption, to recycle wastewater on-site for nondrinking purpose, e.g. irrigation and toilet flush. Provided incentives are investment cost subsidies and tax reductions [31].

A more sustainable management of nutrients and organic wastes from urban areas has not yet been addressed in regulations or is supported by specific incentive systems. The development of new and innovative systems is therefore primary driven by marketing concepts and ideas to create demands for new products. An example for the decentralized collection, transport and thermal composting of organic waste from residential buildings, a decentralized thermal fermentation and dehydration system, is the so-called Zero Food Waste System (ZFWS). In the ZFWS food waste is mixed with wood chips, which have to be transported to the treatment site. The food waste is thermally composted together with wood chips in order to reduce the humidity of the resulting composted product. Prototypes have a treatment capacity of $50 \mathrm{Kg}$ food waste per day and have an expected electric energy consumption of $10 \mathrm{KWh} /$ day $(200 \mathrm{Wh} / \mathrm{Kg}$ food waste). The food waste has to be mixed 1/1 with wood chips [32], which have to be produced and transported to the decentralized treatment site. Accordingly the transport effort for the wood-chips to be involved in the energy intensive on-site treatment process is similar to the conventional transport of decentralized collected organic food waste to a centralized composting site for the production of soil supplement. The resulting product from the ZFWS systems can be either used as a soil supplement or be combusted. However, considering the electricity consumption of the decentralized treatment system, and the need for the production and transport of wood chips, it is questioned if the ZFWS does meet the criteria for a zero emission concept.

Even though a comprehensive approach for addressing the reduction of emissions in the South Korean building sector is neither reflected in current policies nor regulations, public and private sectors have invested a lot of effort to develop and realize sustainable buildings. Some of the sustainable buildings that have been realized in the Republic of Korea meet also zero emission building criteria, which are defined in the framework of the research described in the framework of this paper. The following section discusses selected examples of such Zero Emission Buildings in the Republic of Korea.

\subsection{Examples of Zero Emission Buildings in Korea}

Worldwide, several hundred realized building address the topic of net zero energy buildings. More than 300 buildings, most of them located in Europe, have been already identified in 2010 [33]. Such buildings are also defined as zero emission buildings, but refer to net zero carbon dioxide emissions related to the operation of net zero energy buildings [34] only, and do not address other emissions. In the framework of the ZEBISTIS research project it was challenging to identify realized examples of contemporary ZEBs which meet the comprehensive approach and definition of ZEBs: The operation should not produce any harmful emissions, neither to the atmosphere, to water nor to the ground, but on the contrary should have even positive environmental impacts due to the production of resources such as renewable energy, fresh water, biomass and fertile soil. 
For identification of potential ZEBs an assessment system was developed [35], which considers the quantification and evaluation of resource flows within the system boundary defined by the physical boundary of a building site (property). With the "ecological scarcity method" ecological impacts of emissions to air, surface waters, groundwater, and soil as well as the consumption of resources and the production of wastes can be measured, evaluated and weighted with "eco-points" [36]. The required life cycle assessment data for the calculation of eco points for selected ZEBs in Switzerland and Korea has been mainly retrieved from the KBOB list [37], the Ecoinvent database [38], and have been supplemented with own calculation for parameters which have not been available in any databases [35].

Based on a literature survey, buildings, which could potentially serve as ZEB case studies were selected and it was analyzed to which degree the sectors biomass, energy, and water were addressed in the zero emission concept of the specific buildings. Only buildings that addressed at least two eligible processes of at least two of the three sectors biomass, energy and water were considered to address sectors and processes (Table 2, [35]) according to the ZEB concept sufficiently. For the evaluation of potential ZEBS also an additional sector for qualitative and superior aspects has been created. (Table 2) [35].

\begin{tabular}{|c|c|}
\hline $\begin{array}{l}\text { Sector } \\
\text { (Eco-point assessment units) }\end{array}$ & $\begin{array}{l}\text { Eligible processes } \\
\text { (at least } 2 \text { processes have to be addressed by ZEBs in } 2 \text { of the first } 3 \text { sectors) }\end{array}$ \\
\hline $\begin{array}{l}\text { Biomass } \\
(\mathrm{Yes} / \mathrm{No})\end{array}$ & $\begin{array}{l}\text { - } \text { Composting of organic waste } \\
\text { - } \text { Composting of faeces } \\
\text { - } \text { Nutrient recovery from urine } \\
\text { - } \text { Food production } \\
\text { - } \\
\text { - } \\
\end{array}$ \\
\hline $\begin{array}{l}\text { Energy } \\
(\mathrm{kWh} / \mathrm{a}, \mathrm{MJ} / \mathrm{a})\end{array}$ & $\begin{array}{l}\text { - } \text { Photovoltaic generators } \\
\text { - Solar thermal collectors } \\
\text { - Wind turbines } \\
\text { - } \quad \text { Geothermal energy use } \\
\text { - Highly insulated building envelope } \\
\text { - } \quad \text { Passive solar energy use } \\
\text { - Heat recovery } \\
\text { - Use of waste heat }\end{array}$ \\
\hline $\begin{array}{l}\text { Water } \\
\left(\mathrm{m}^{3} / \mathrm{a}\right)\end{array}$ & $\begin{array}{l}\text { - } \text { Rainwater harvesting } \\
\text { - Water saving devices } \\
\text { - } \\
\text { - } \\
\text { - } \\
\text { Recentralize of water wastewater treatment } \\
\text { Urine separation }\end{array}$ \\
\hline $\begin{array}{l}\text { Additional } \\
\text { (Applies fully, partly or not) }\end{array}$ & $\begin{array}{l}\text { - } \text { Good connection to public transport } \\
\text { - Integration of greenery on roof and in façade } \\
\text { - } \quad \text { Building construction is easily adaptable to different building uses } \\
\text { - } \text { Building is constructed with environmental friendly materials } \\
\text { - Low grey energy content of building construction } \\
\text { - Building design fits to the surrounding environment }\end{array}$ \\
\hline
\end{tabular}

Table 2. Sectors and eligible processes, and assessment units for the selection of ZEB case studies and the calculation of eco-points. 
As a result 4 buildings in Switzerland and 1 building in the Republic of Korea, that fulfill the previously defined ZEB criteria sufficiently, have been identified. The buildings in Switzerland are: Umwelt Arena in Spreitenbach (2012), Forum Chriesbach in Duebendorf (2006), New Monte Rosa Hut in the Alps of South Switzerland (2005), and the Aquamin building in Zuchwil (2007). The building in the Republic of Korea is the Kolon e+ Green Home in Kyeong Gi (2010) (Table 3, [35]).

According to the result of the evaluation results, the Forum Chriesbach in Switzerland and the Kolon e+ Green Home in Korea are the buildings with the most balanced approach to the three addressed zero emission sectors. The two buildings have also the least impact on the environment (expressed by a low number of eco-points and a high degree of ZEB achievement). Subsequently the zero emission concept of the Kolon e+ Green Home are discussed more detailed. The Swiss case studies are not presented because this would go well beyond the scope of this paper about ZEBs in Korea.

\begin{tabular}{|c|c|c|c|c|c|}
\hline $\begin{array}{c}\text { Case Study- } \\
\text { Building name }\end{array}$ & $\begin{array}{c}\text { Umwelt Arena } \\
\text { Spreitenbach }\end{array}$ & $\begin{array}{c}\text { Forum } \\
\text { Chriesbach } \\
\text { Duebendorf }\end{array}$ & $\begin{array}{c}\text { New Monte } \\
\text { Rosa Hut }\end{array}$ & $\begin{array}{c}\text { Aquamin } \\
\text { Zuchwil SO }\end{array}$ & $\begin{array}{c}\text { Kolon e+ } \\
\text { Green Home }\end{array}$ \\
\hline Country & Switzerland & Switzerland & Switzerland & Switzerland & Korea \\
\hline Building type & Event center & Office & Hotel & $\begin{array}{c}\text { Single-family } \\
\text { house }\end{array}$ & $\begin{array}{c}\text { Single-family } \\
\text { house }\end{array}$ \\
\hline $\begin{array}{c}\text { Degree of ZEB } \\
\text { achievement }\end{array}$ & $90.97 \%$ & $\mathbf{9 7 . 3 9 \%}$ & $81.64 \%$ & $92.28 \%$ & $\mathbf{9 3 . 6 9 \%}$ \\
\hline Eco-points $m 2$ & 18,065 & $\mathbf{5 , 2 2 1}$ & 41,314 & 14,673 & $\mathbf{1 1 , 9 8 6}$ \\
\hline \multicolumn{7}{|c|}{ Proportion contribution to eco-point calculation divided by sectors: } & $23 \%$ & $\mathbf{2 5 \%}$ \\
\hline Biomass & $49 \%$ & $\mathbf{1 \%}$ & $77 \%$ & $\mathbf{1 0 \%}$ \\
\hline Energy & $34 \%$ & $\mathbf{3 3 \%}$ & $13 \%$ & $54 \%$ & $1 \%$ \\
\hline Water & $8 \%$ & $\mathbf{3 5 \%}$ & $0 \%$ & $\mathbf{5 2 \%}$ \\
\hline Additional & $9 \%$ & $\mathbf{3 1 \%}$ & $10 \%$ & $10 \%$ & $\mathbf{1 3 \%}$ \\
\hline Total & $100 \%$ & $\mathbf{1 0 0 \%}$ & $100 \%$ & $100 \%$ & $\mathbf{1 0 0 \%}$ \\
\hline
\end{tabular}

Table 3. Comparative overview of the ecological impact of ZEB case studies in Switzerland and in Korea with information regarding the proportional contribution of specific zero emission sectors to emission reduction.

Kolon e+ Green Home is a detached single-family house that has been realized by Kolon institute of Technology with the strategic partners Unsangdong Architects Cooporation, Korean Institute for Construction Technology (KICT), Fraunhofer Institute for Solar Energy (ISE), Hanil Mec.Elec. Consultants, and CVnet Corporation. Furthermore 6 build partners and 29 supply partners have been involved in the design, planning and construction, operation and monitoring processes of the building. The building has been finalized in 2010 and is located in Kyeong Gi on the property of the Kolon headquarters (Figure 8, Sergio Pirrone on [39]). In the recent years the building has been operated and monitored. The first years the building has not been occupied by building users. Therefore, the influence of occupants had to be considered by adjustment of monitoring results, e.g. based on 
experiences in other buildings. In 2014 the building is occupied and utilized in order to validate the monitoring results and calculation from the previous years [40].

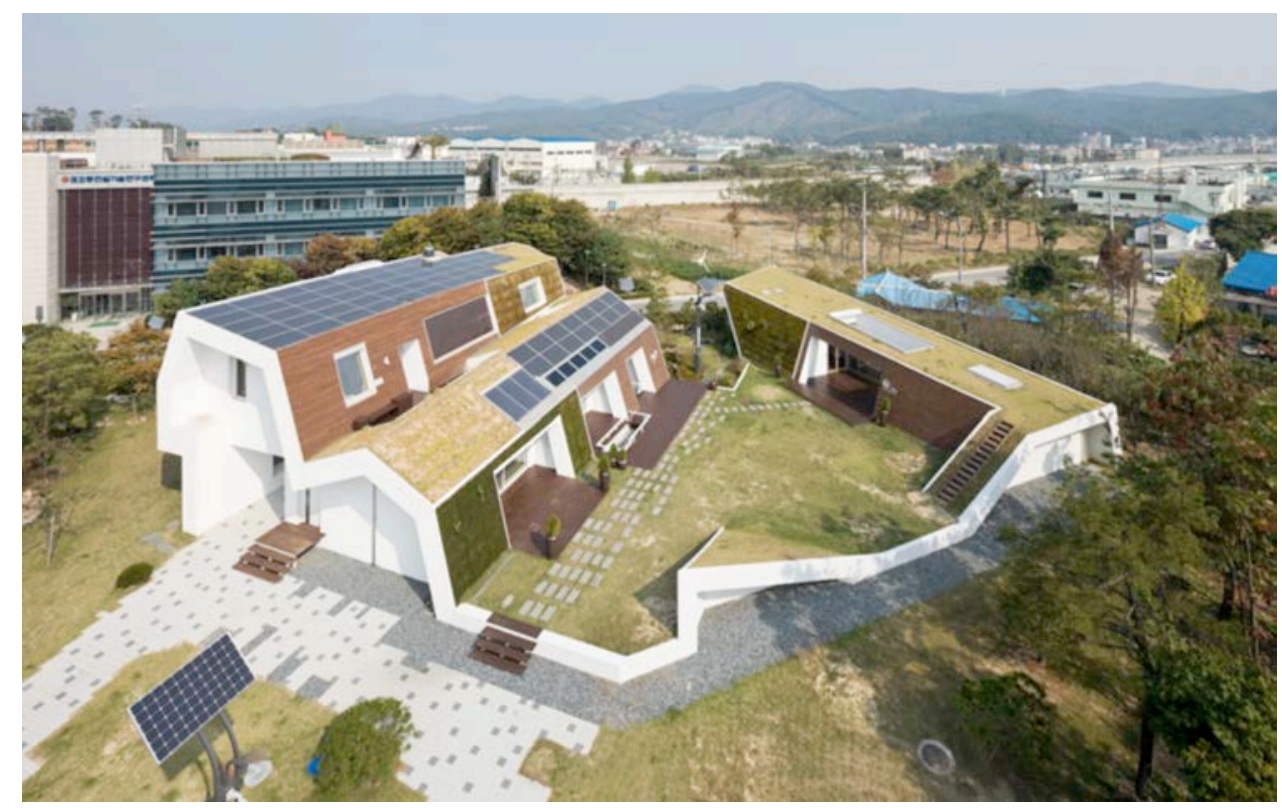

Figure 8. Aerial view of Kolon e+ Green Home. Well visible are the greened roof, facades, roof-integrated PV generators and solar thermal collectors. The Kolon headquarter building is visible in the background left.

The building is very energy efficient, complies with the 33 criteria defined by the German Passive House institute has been accordingly certified as a Passive House. The electric energy consumption is $531 \mathrm{kWh} / \mathrm{a}$ and the building's useful area is $295 \mathrm{~m}^{2}$. Accordingly, the electric energy consumption is only $1.82 \mathrm{kWh} / \mathrm{m}^{2} \mathrm{a}$. The building is connected to the public electricity grid and does not work with electric energy storages. The building can therefore be defined as a lowest energy or nearly net zero energy building. The building is equipped with 95 different green technologies, which contribute to the energy, water and resource efficiency of the building and aim for the provision of a comfortable and healthy indoor climate. An overview of the location and function of selected features is provided in Figures 9 [39].

Mitigation of heat island effects, evaporation of water and passive cooling, as well as the retention of rainwater is increased by extensive greening of some of the building's roof and façade surfaces. For the reduction of the drinking water consumption, the building is equipped with water saving appliances, such a faucets, showerheads and toilets, rainwater harvesting and utilization and a greywater recycling system. For the building construction the utilization of ecological materials has been addressed. However nutrient and biomass aspects have been not addressed considerably in the building project [40].

According to the ZEB assessment system [35] developed in the framework of the ZBISTIS project [8] the buildings presented subsequently could also be defined as ZEBs because they address multiple aspects which are eligible for ZEBs. However quantification of the building performance is not feasible in the framework of this paper, because the buildings are either not operated according to its 
appointed building use, or no data for the quantification of the building performance was available during the writing of this paper.

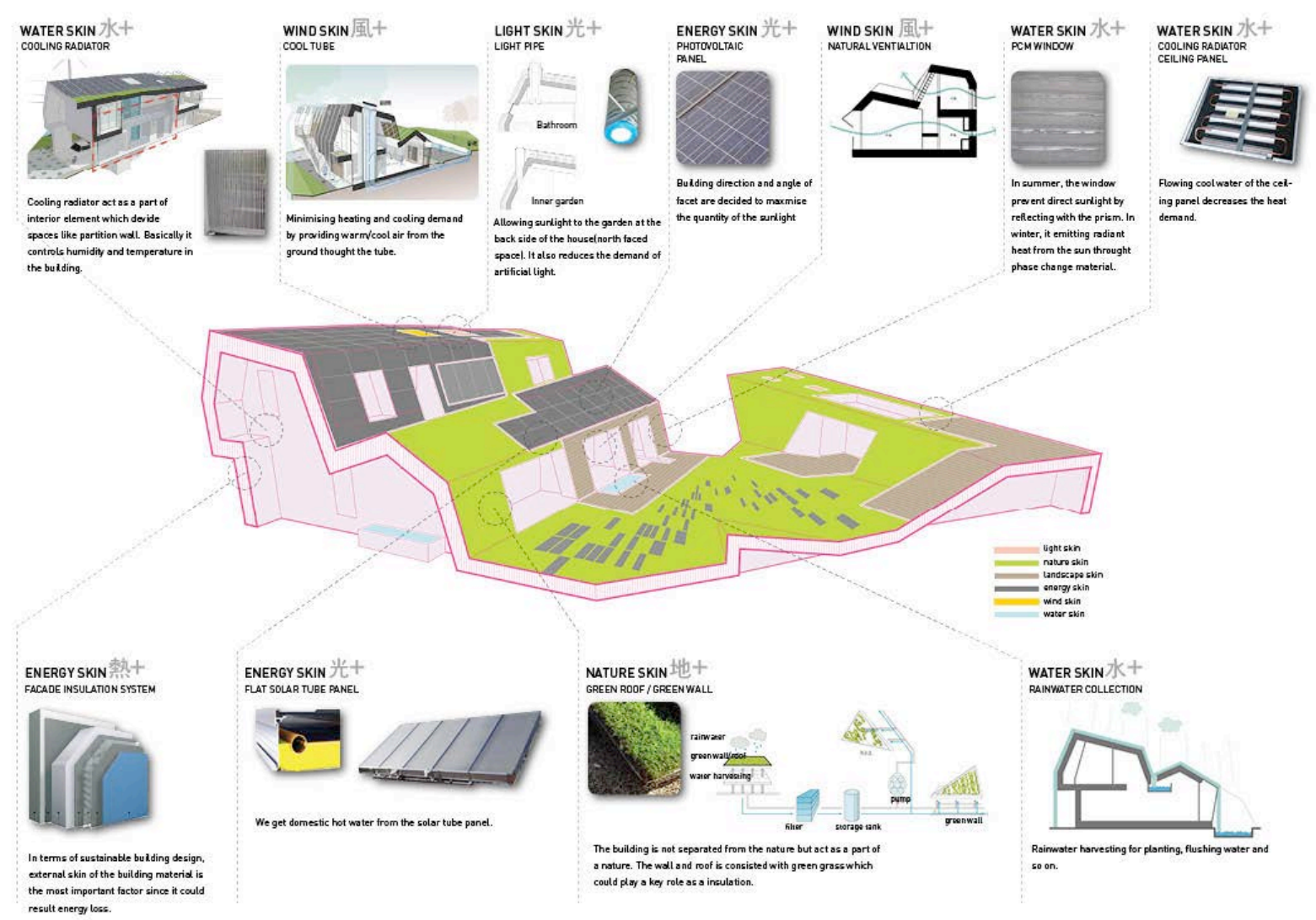

Figure 9. Isometric drawing of Kolon e+ Green Home with location and brief description of measure contributing to the building's energy and water efficiency

Samsung Green Tomorrow is a single-family house, owned by Samsung C\&T Corp. It was planned designed and and built by Samsung in collaboration with Samoo Architects and Ove Arup \& partners. It is located in Gyeonggi-Do and has a useful area of $423 \mathrm{~m}^{2} .66$ Green features are addressed and first project in East Asia achieving LEED Platinum award. Samsung plans also to apply the green concepts utilized in Green Tomorrow to its residential construction projects in in order to cut the buildings energy consumption and improve sustainability [41]. However, the building is not used according to its purpose as residential building and serves primary as a showcase for cutting edge technologies and design ideas, which facilitate the realization of sustainable buildings. The single story design with very low density and comparable high living area for one family already indicates, that this building does not aim to be a model home for the majority of the Korean population, but a luxurious and outstanding example of a green building. The general building concept (ecological materials, net zero energy consumption and reduced water footprint by rainwater harvesting, management, utilization and greywater recycling are basically comparable with Kolon e+ Green Home. However Samsung Green Tomorrow includes electric energy storage and connection to electric cars in its concept. 
The first pilot project for sustainable high-rise apartments in South Korea, "greenhome plus" has been built from 2006 to 2010 in Songdo, a newly developed district on reclaimed land in the coastal area of the city Inchon. The building has been developed by the company Daelim in cooperation with the Yonsei University and approx. 30 other organizations. In greenhome plus „green“ building concepts and technologies are applied, which are comparable with those Kolon e+ green home, but adapted to a building typology, which is suitable for high-rise apartment buildings. Different experimental houses for Green Home Plus with energy saving rates of $40 \%, 60 \%, 80 \%$ in comparison with standard apartments, and zero energy houses have been realized.

Nutrient and Biomass aspects are also not addressed in the greenhome plus building project. Regarding the water sector the building uses water saving technologies and combines a rainwater harvesting and management with a grey water recycling system. The heating and cooling energy demand are reduced by external thermal insulation, double windows with external blinds and heat absorption glazing, mechanical ventilation systems with heat recovery and low temperature radiant heating and cooling systems. The required heating and cooling energy demand is provided by water-towater heat pumps using low-temperature geothermal energy. Renewable electricity is produced with roof and façade integrated PV-panels while façade integrated vacuum tube collectors support warm water production and heating systems. On roof surface areas, which are not equipped with PV generators, the building is equipped with extensively and intensively greened roofs (Figure 10 [42]).

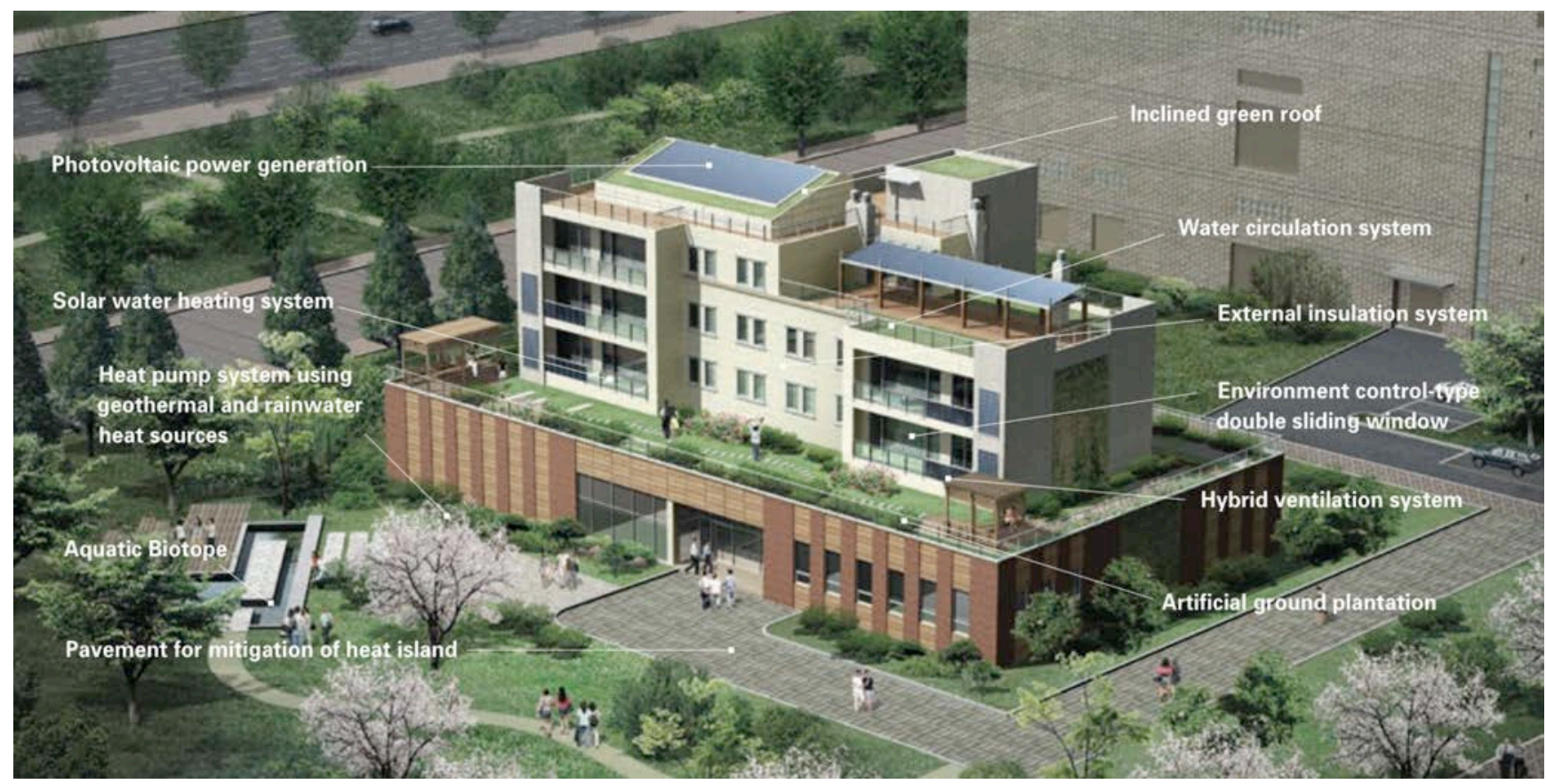

Figure 10. Isometric view of greenhome plus with indication of the main building integrated features for greening, water and energy management, and renewable energy production.

In addition to the buildings discussed above, the following Korean buildings address energy efficiency and productivity measures: 
- "Climate Change Research Center" in Inchon is research office building with conference facilities and an outstanding example for a building with constructively and aesthetically integrated BIPV [43].

- "Energy Dream Center" in Seoul combines offices, exhibition space and conference facilities meets the German Passive House criteria, is equipped with roof mounted PV generators [43] and is presumably Koreas biggest and most energy productive building (net + energy building). In 2013 the building produced much more electric energy with PV than it required for operation. Rainwater is collected, infiltrated and used for irrigation.

- "Post Office Seonam" in Sampyeong is a net zero energy office building with roof an façade integrated PV generators and was the first zero-carbon business building in Korea. The building received the $1^{\text {st }}$ prize of the Korea Green Architecture Awards and won the technical award of Korea Ecological Architecture and Environment Grand Prize [44].

- "Zero Carbon Green Home" in Ilsan is a net zero energy multi family apartment building, realized by KICT \& TOP and aims to facilitate research and development of future apartment buildings under real life conditions [45].

\section{Conclusions}

Based on the findings presented in the framework of this paper it can be concluded that Korea has a long history in sustainable living as well as the construction and operation of zero emission buildings. However, during the $20^{\text {th }}$ century much of the ancient knowledge and practice has been forgotten. Rapid modernization and development processes in Korea resulted in the area wide adaptation of international standards in urban development and architecture. Such standards are generally not meeting zero emission criteria. Since the beginning of the $21^{\text {st }}$ century a growing interest in green and sustainable development can be observed in Korea. Recent research and development projects by public and private actors address the reduction of resource consumption and emissions to the environment. Comparable with international trends, the primary focus of zero emission concepts in Korea is on the combustion of fossil fuels and the related $\mathrm{CO}_{2}$ emissions. Accordingly strategies to increase energy efficiency and production of renewable energy are standing high on the national agenda. The second important issue addressed is the reduction of water consumption by water saving appliances, the recycling of wastewater, as well as rainwater harvesting, utilization and management. The latter is also related with retention of stormwater and therefore also important for flood control, the avoidance of damages in urban infrastructure and adaptation of the effects of climate change.

The presented case studies of sustainable building projects illustrate that zero emission buildings can be principally realized in the Republic of Korea. However, the majority of built examples, addressing multiple zero emission sectors, are not yet operated under "real life" conditions and function as case studies for further research and development. Furthermore the presented single-family houses are not representative for the Korean Housing market, which is mainly in the segments of multi-family and apartment buildings.

Building companies regard the further development of energy efficient and resource productive buildings presently as economically not attractive and feasible. An important reason are the comparable low consumer prices, e.g. for energy and water, and a lack of compulsory requirements, 
such as energy performance certificates and building codes, which aim for higher energy and resource efficiency. Obviously currently achievable monetary savings by reduction of operation costs, through realization of energy efficient and resource productive buildings, and living quality improvement do not facilitate the development of profitable zero emission business models for construction companies and real-estate developers.

The densification of cities in order to accommodate increasing numbers of population, and to avoid vast urban sprawl and transportation needs, is widely accepted as a sustainable urban development strategy. However, green spaces are of vital importance for a high living quality [46], and they play an important role for the accommodation of sustainable infrastructure systems based on the principles of a circular flow economy involving the effective and local management and production of renewable resources, such as organic wastes, water and food. The densification of urban environments reduces the available land area for urban green spaces within such urban developments. Accordingly, and in analogy to the concept of an edificial densification, it is necessary to develop both concepts for the densification of urban green spaces and the provision of more green spaces in built up urban areas. Urban green spaces of housing developments could be for example re-interpreted as multifunctional productive garden rooms for the provision of a better living quality and more well-being of urban population in the neighborhoods, and the accommodation of nature orientated and ecological sound urban infrastructure systems.

\section{Acknowledgments}

The authors would like to thank all partners from the Koranet Zebistis project for fruitful cooperation and discussions. This work was supported by funding received from the KORANET Joint Call on Green Technologies, www.koranet.eu.

\section{Conflict of Interest}

The authors declare no conflict of interest.

(C) 2014 by the authors; licensee MDPI, Basel, Switzerland. This article is an open access article distributed under the terms and conditions of the Creative Commons Attribution license.

\section{References}

1. UNEP - United Nations Environment Programme Buildings and Climate Change Summary for Decision-Makers; UNEP DTIE Sustainable Consumption and Production Branch: Paris, France, 2009; p. 62.

2. Lüthi, C.; Panesar, A.; Schütze, T.; Norström, A.; McConville, J.; Parkinson, J.; Saywell, D.; Ingle, R. Sustainable Sanitation in Cities - A Framework for Action; First ed.; Papiroz Publishing House, The Netherlands: 2011; p. 169.

3. Schuetze, T.; Lee, J.-W.; Lee, T.-G. Sustainable Urban (re-)Development with Building Integrated Energy, Water and Waste Systems. Sustainability 2013, 5, 1114-1127.

4. DWA Deutsche Vereinigung für Wasserwirtschaft, A.u.A.e.V. Neuartige Sanitärsysteme; 1 ed.; DWA: Hennef, Germany, 2008; Vol. 1, p. 327. 
5. Schuetze, T. Dezentrale Wassersysteme im Wohnungsbau internationaler Großstädte am Beispiel der Städte Hamburg in Deutschland und Seoul in Süd-Korea; Books on Demand: Norderstedt, Germany, 2005; p. 496.

6. Binz, C.; Larsen, C.; Maurer, M.; Truffer, B.; Gebauer, H. Zukunft der dezentralen Wassertechnologien; EAWAG: Dübendorf, Switzerland, 2010.02.01-02, 2010; p 59.

7. Schuetze, T.; Tjallingi, S.P.; Correlje, A.; Ryu, M.; Graaf, R.; Van der Ven, F. Every drop counts : environmentally sound technologies for urban and domestic water use efficiency; 1 ed.; United Nations Environment Programme: Nairobi, Kenya, 2008; p. 197.

8. Schuetze, T.; Runge, R. Zero Emission Building - Integrating Sustainable Technologies and Infrastructure Systems. Available online: http://www.zebistis.ch/index.php?option=com_content\&view=article\&id=3\&Itemid=103

9. Heinrichs, G.; Westphal, H. Korean scientific cooperation network with the European Research Area - 2012 Joint Call on Green Technologies. Available online: http://www.koranet.eu/en/229.php (2014.09.26),

10. Schuetze, T.; Willkomm, W. Klimagerechtes Bauen in Europa; University of Applied Sciences Hamburg, Department of Architecture: 1999; p 84.

11. Lee, E.H. Gebäude-Freiraum-Beziehungen im Zuge der Siedlungsentwicklung in Korea : unter besonderer Berücksichtigung ökologisch orientierter Bauweisen und des schonenden Umgangs mit Ressourcen; TU Berlin: Berlin, Germany, 1995; p. 257.

12. Kim, H.S. Ökologisch orientiertes Wohnen und Bauen in Korea - Tradition und Chance; University Hanover Hanover, Germany, 1993; p. 142.

13. Schuetze, T.; Willkomm, W. Umweltauswirkungen nachträglicher Veränderungen an städtischen Wohnungsbauten; University of Applied Sciences Hamburg, Department of Architecture: Hamburg, Germany, 2001; p 66.

14. SDI; Institute for Seoul Studies Seoul Twentieth Century: Photographical History of the Last 100 years; Seoul Development Institute SDI: Seoul, Republic of Korea, 2000; p. 384.

15. Oh, Y., Drawings of traditional Korean sanitation. In Seoul, Republic of Korea, 2010.

16. Lee, D.B. The dream of the nature-orientated toilette "Dickan"; Seoul, Republik of Korea, 2000 .

17. Kim, J. Analyse der Raumgestaltung in der Architektur und darauf basierende Untersuchung einer Wohnanlage in Korea; University Stuttgart, Department of Architecture and Urban Planning: Stuttgart, Germany, 1994; p. 213.

18. Kim, Y.; Choe, S.-C. Seoul: The Making of a Metropolis; Wiley: New York, USA, 1997; p. 278.

19. Kwon, W.-Y.; Kim, K.-J., Urban Management in Seoul - Policy Issues and Responses; Seoul Development Institute: Seoul, Republic of Korea, 2001; p. 178.

20. Seoul Metropolitan Government Seoul Water Works Report 2002; Seoul Metropolitan Government Seoul, Republic of Korea, 2003.

21. Schuetze, T.; Santiago-Fandiño, V. Quantitative Assessment of Water Use Efficiency in Urban and Domestic Buildings. Water 2013, 5, 1172-1193.

22. Korea, M.o.E.R.o., Environmental Statistics Yearbook 2002; Ministry of Environment Republic of Korea: Seoul, Korea, 2002.

23. Korea Water Resources Corporation Water Resources Development; Korea Water Resources Corporation,: Daejon, Korea, 2002.

24. Plant, T.S.T., Sewage Treatment. In Plant, T. S. T., Ed. Tanchon Sewage Treatment Plant: Seoul, Republic of Korea, 2004.

25. Yoon, Y.S., Zero Energy Buildings in Korea - Korea Energy Policies for Sustainable Building. In Zero Enery Building Workshop 2012, Fraunhofer Representative Office Korea: Energy Dream Center, Seoul, Republic of Korea, 2012; Vol. 1, p 14.

26. Chun, S.; Korean Energy Management Cooperation, Building Energy Policies in Korea. In International Workshop EPC (Energy Performance Certificate) and Assessor System for 
Buildings Korean Energy Management Cooperation: Seoul Olympic Parktel, Seoul, Korea, 2012.

27. Kim, S.A. Policy and Technology of Housing Remodeling in Korea; Korea Institute of Construction Technology: Ilsan, Korea, 2003.

28. Chung, I.-U., The current status of old apartments and the remodeling policies in Korea. In World Cities Summit, World Cities Summit: Singapore, 2014; p 21.

29. Lee, T.-G. Sanierungspolitik und Sanierungsmassnahmen in Berlin (Ost) nach der Wiedervereinigung und in Seoul; TU Berlin, Department of Architecture: Berlin, Deutschland, 1998; p. 256.

30. Choi, K.B. In Seoul's Policies on Parks and Green Spaces, The 3rd International Workshop on ILTER Ecological Information Management in the East Asia-Pacific Region, Kookmin University, Seoul, Korea 2007.10.16, 2007; KLTER: Kookmin University, Seoul, Korea 2007; pp. 1-41.

31. Ministry of Environment Republic of Korea Green Korea 2001; Ministry of Environment Republic of Korea,: Seoul, Republic of Korea, 2001; p. 77.

32. Jeong, I.O., Application of Zero Food Waste System with Fermentation-Extinction Technology to the Apartment Complexes in Korea In 1st Symposium on Green Infrastructure and Future City \& 4th International Symposium ZEBSITIS, Land and Housing Institute \& Sungkyunkwan University: Seongnam, Republik of Korea, 2014; Vol. 1, pp 137-157.

33. Musall, E.; Weiss, T.; Lenoir, A.; Voss, K.; Garde, F.; Donn, M., Net Zero energy solar buildings: an overview and analysis on worldwide building projects. In EuroSun 2010, International Solar Energy Society (ISES) IEA Solar Heating \& Cooling Programme (SHC): Graz, Austria, 2010.

34. Voss, K.; Musall, E.; Lichtmeß, M. From Low Energy Energy Buildings to Net Zero-Energy Buildings: Status and Perspecives. Journal of Green Building 2011, 6, 12.

35. Buehler, D. Best Practices of Zero Emission Buildings in Switzerland. Bachelor Thesis; Zuerich University of Applied Sciences: Waedenswil, Switzerland, Country, 2013.

36. Frischknecht, R.; Steiner, R.; Jungbluth, N. The Ecological Scarcity Method - Eco-Factors 2006 - A method for impact assessment in LCA; Federal Office for the Environment FOEN: Bern, Switzerland, 2009.06.19, 2009; p 188.

37. Bächtold, H.; Egli, N.; Frei, K.; Friedli, R.; Frischknecht, R.; Gugerli, H., Empfehlung Nachhaltiges Bauen - Ökobilanzen im Baubereich. In KBOB; eco-bau; IPB, Eds. KBOB: Switzerland, 2012.

38. Ecoinvent Ecoinvent Database. Available online: http://www.ecoinvent.ch (2014.09.15),

39. ArchDaily E+ Green Home / Unsangdong Architects. Available online: http://www.archdaily.com/273244/e-green-home-unsangdong-architects/ (2014.09.15),

40. Kim, J.N.; Kolon, Interview Kolon e+ Green Home. In Schuetze, T., Ed. 2013.

41. Arup Green Tomorrow. Available online: http://www.arup.com/projects/green tomorrow.aspx

42. Daelim Corporate Planning 1 Team, DAELIM 2011 Sustainability Report - Construction of Low-energy Eco-friendly 'Green Home Plus'. In Daelim Industrial Co. Ltd., Ed. Daelim Industrial Co. Ltd.,: Seoul, Korea, 2011.

43. Schuetze, T. Integration of Photovoltaics in Buildings - Support Policies Addressing Technical and Formal Aspects. Energies 2013, 6, 2982-3001.

44. Korea Post 2012 Korea Post Annual Report; Korea Post: Seoul, Korea, 2013.05, 2013; p 76.

45. Won, J.S., Examples in Korea. In Zero Enery Building Workshop 2012, Fraunhofer Representative Office Korea: Energy Dream Center, Seoul, Republic of Korea, 2012; Vol. 1.

46. Arnberger, A. Urban Densification and Recreational Quality of Public Urban Green Spaces-A Viennese Case Study. Sustainability 2012, 4, 703-720. 